\title{
An Investigation on the Earnings Quality in companies (Evidence from Iran)
}

\author{
Bahram Meihami ${ }^{1, *}$, Zeinab Varmaghani ${ }^{2}$, Hussein Meihami ${ }^{3}$ \\ 1Department of Accounting, Ghorveh Branch, Islamic Azad University, Ghorveh, Iran \\ 2BA Student of Primary Education, Ghorveh Branch, Islamic Azad University, Ghorveh, Iran \\ ${ }^{3}$ Department of English Language Teaching, Ghorveh Branch, Islamic Azad University, Ghorveh, Iran \\ *Email address: meyhami4@gmail.com
}

\begin{abstract}
A considerable focus of bottom-line income losses is important in the case of investigating quality of earnings. The future of stock returns is all associated with accruements that are in relation with reliability, and negativity. Earning increases that are accompanied by high accruals, suggesting inferiority of earnings, are related with poor future returns. This study describes the investigation of different hypotheses earnings manipulation, extrapolative fundaments about future growth, and under reaction to changes in business conditions to explain accruals' predictive power. Differentiations between the hypotheses are grounds on operating performance, the behavior of individual accrual items, discretionary versus fixed investment trust components of accruals, and special items. In the main hypothesis we tested stock return and Earning Quality separately. In this investigation firms in according to a mount of accruals. Later on the validity using within-industry comparisons, and data on Tehran stocks was checked. This means that earnings management occurs with a time lag by market participants. In this research it was indicated that components of accruals including changes in accounts receivable, inventory, other current assets, current liabilities and other current liabilities have not significant effect on stock return. It was also indicated that for discretionary accruals, decreasing of stock return is greater than the decreasing of stock return for non-discretionary accruals.
\end{abstract}

Keywords: Earnings Quality; Stock Returns; accruals item; discretionary and nondiscretionary accruals item

\section{INTRODUCTION}

Accounting earnings and its elements that are figured on the basis of accrual method are considered when managers and creditors wish to make decisions. Accrual approach requires that revenues and expense items should be realized. Realization doesn't mean necessarily that cash should receive or pay via transaction when earnings are calculated estimations and predictions accomplished (Brown, 2001). But how much do we accept such accrual earnings for decision making? Managers often have some discretion when they use realization and matching principles and this has effects "earnings quality". while we anticipate that mangers are more aware about their own entities and they can provide more information about economic transactions and events, personal welfare and self interest intention such as compensations, rewards and retention in the firm may persuade that managers to manipulate earnings. Then 
again, earnings quality is the function of mangers bonuses. In this research we select one aspect of earnings quality (Collins, 1989). Then we measure that one aspect for performance evaluation. Measurement is based on cash and accrual components of earnings. Hence, our purpose in this research is to determine the function of accruals on earnings quality. In the next section we describe the literature, then we discuss about research Hypothesis and methodology and finally we analyze data and hypothesis. The last section is the conclusion in which we are going to summarize our research findings ( Zohdi et all, 2012).

\section{1. Literature Review}

According to SFAC1 of Financial Accounting Standards Board (FASB) users of financial statements can make different decisions when they have information about earnings [1]. These are: 1- evaluation of management performance 2- assessment of earnings power in a long-term horizon 3-prediction of earnings for the future and 4- estimation the risk of investing or financing the firm. It is important to have this in mind that the quality of earnings when we decide to use accounting figures. "Earnings quality" has different definition, so researchers have not specific definition about earnings quality. We can divide earnings quality (EQ) subject in to three categories: earnings persistence, level of accruals and earnings that are reflection of economic transactions. Earnings persistence means the continuation of current earnings. The more earnings persistence the more proposed EQ because it is presumed that the power for maintenance of current earnings increases. (Warfield, 1992), argues that EQ depends on the type and amount of Accounting Information based on contracts. They define earnings quality in terms of economic income and according to usefulness for decision making. We argue as much as reported earnings help us to decide better, those figures have more qualities. However because individuals have different ideas and decisions, we cannot present a comprehensive definition of EQ. The usefulness of Earnings numbers is related to other factors. For example abilities of users to analyze non-financial information numbers should be considered.

\section{2. The importance of earnings quality}

In this research, we first examine the potential importance of looking beyond the bottomline earnings number and considering accruals as well. The cross-sectional predictive power of earnings surprises for future returns is widely documented for example (Lougee, 2001). However, it may not be meaningful to compare firms with large and small earnings without some adjustment to separate cases where firms are improving their underlying cash flow performance from cases where they may be "cooking the books" (Lougee B. \& Marquardt C., 2004). Table 3 checks whether we can refine the predictive power of earnings surprises for returns by taking into consideration accruals as a measure of the quality of earnings or not (Hand, 1989). In Table 4 stocks are assigned to portfolios on the basis of a two-way classification. Stocks are grouped at the end of each April over the sample period into one of five categories based on earnings surprise. Our indicator of earnings surprise is the change in earnings from a year ago, relative to average total assets. At the same time stocks are independently sorted into quintile groups based on accruals relative to average total assets. The point of intersection of these two categorizations gives twenty five categories; stocks return are equally weighted within each group. We announce annual buy-and-hold returns and abnormal returns for each portfolio in the first year after portfolio formation. Size and book-to-market adjusted abnormal returns are computed. We calculate quintile breakpoints for market value of equity each April. Since the bottom quintile of firms contains large number of firms which are out of proportion, we break this group out into two classifications. Accordingly there are six 
categories by firm size. Apart from others, we calculate quintile breakpoints for the ratio of book-to-market value of equity. The intersection of these two classifications gives thirty groups. We calculate buy-and-hold returns for equally-weighted portfolios of the stocks within each group. Based on where a stock falls given the size and book-to-market breakpoints, it is attributed one of these portfolios as a control. The abnormal return for a stock is the difference between its raw return and the return of the control portfolio. In accordance with results from the previous studies, a measure of earnings surprise predicts stock returns. To calculate the marginal contribution of earnings surprise, we calculate the spread in returns between the top and bottom quintiles by earnings surprise for each of the five categories of accruals. The spreads are reported in the last row of each panel in Table 4 The average spread in stack returns is 4.2 percent per year. Significantly, the marginal contribution of accruals is larger. From the last column in panel B, the spread in abnormal returns between the top and bottom quintiles by accruals averages 6.2 percent. Even when the earnings surprise is most favorable and one expects positive abnormal returns on the basis of prior research, abnormal returns turn out to be negative if accruals are high. When accruals are high, abnormal returns are negative across all classifications of earnings surprise. Holding fixed earnings surprise, returns become more disappointing as accruals rise. To sum up, the evidence in Table 5 are suggesting that the market may be currently misled by ignoring information about the quality of earnings, as proxies by accruals.

\section{3. Earning quality and stock return}

Most researchers found that earning quality is directly associated with stock return. Lev and believed that the companies with high earning quality have high future income growth. and found that stock with high accrual items (low earning quality) are with low return, it means that there is reverse relation between accrual items and stock return or there is direct association between earning quality and stock return showed that accrual items are negatively associated with stock return. Increasing earning along with high accrual items refer to low earning quality and its low relevance with future return (Khajavi P. \& Nazemi A., 2005). showed that there is direct association between earning quality and stock return. Earnings quality measurement models:

Jones Model:

$\mathrm{TAt}=(\Delta \mathrm{CAt}-\Delta \mathrm{CLt}-\Delta \mathrm{CASHt}+\Delta \mathrm{STDEBTt}-\mathrm{DEPNt})$

NDAt $=\alpha 1(1 /$ At-1 $)+\alpha 2(\Delta$ REVt/At-1 $)+\alpha 3($ PPEt/At-1 $)$

Tat: In total accruals in year $\mathrm{t}$

$\triangle$ CAt: Changes in current assets.

$\Delta$ CLt: Change in current liabilities

$\Delta$ CASHt: Change in cash.

$\triangle$ STDEBTt: Change in current portion of loans receivable

DEPNt: Depreciation of tangible assets and the invisible

NDAt: The nondiscretionary accruals in year $t$

REVt $\Delta$ : Income year $\mathrm{t}$

PPEt: Property, plant and equipment, gross in end of period $t$

Modified Jones model: 
TAt $=($ DCAt - DCLt - DCASHt + DSTDEBTt-DEPNt $)$

NDAt/At-1 = a(1/At-1) + a2[(DREVt - DRECt $)+$ a3(PPEt/At-1)

We follow Sloan (1996) and measure accruals as:

Accruals $=\triangle C A-\triangle C L-D E P=(\triangle A R+\triangle I N V+\triangle O C A)-(\triangle A P+\triangle O C L)-D E P$.

$\triangle C A$ is the change in non-cash current assets, given by the change in current assets (Compustat annual data less the change in cash).

$\triangle C L$ is the change in current liabilities excluding short term debt and taxes payable, given by the change in current liabilities. Minus the change in debt included in current liabilities and minus the change in income taxes payable.

$D E P$ is depreciation and amortization. The components are further defined as $\triangle A R$ the change in accounts receivable;

$\triangle I N V$ the change in inventories.

$\triangle O C A$ the change in other current assets;

$\triangle A P$ the change in accounts payable;

and $\triangle O C L$ the change in other current liabilities.

As the magnitudes of all these items vary with the overall size of the firm's balance sheet, we follow the accounting literature and scale each item by average total assets. Since we are interested in firms' operating performance we focus on profitability before financing costs and taxes. Our measure of earnings is thus operating income after depreciation (before interest expense, taxes and special items), corresponding to Compustat annual data. Accruals comprise the changes in various working capital accounts, so to give some perspective we begin by examining the underlying working capital items . Current assets is the dominant item, representing 47.1 percent of total assets for the median firm. Accounts receivable and inventory make up the bulk of current assets, with each item accounting for more than 20 percent of total assets for a typical firm. provides information on the individual accrual items. The largest accrual item is depreciation, but it displays little variability across firms, as evidenced by the low standard deviation. The items that contribute most to differentiating accruals across firms are changes in accounts receivable and changes in inventory. The standard deviation of each of these items exceeds 7 percent. Total accrual displays large cross-sectional variability, with a standard deviation of 10.2 percent. This variability is close in magnitude to the average level of earnings (as a percent of total assets). The implication, then, is that changes in accruals that may not appear unusual can lead to substantial changes in reported earnings.

\section{THE ACCRUAL EFFECT}

The sample comprises all firms listed on the Tehran Stock Exchange which are covered on both the Center for Research in Security Prices (CRSP) file as well as the current and research. Besides, only domestic, primary stocks, investment trusts, and units and foreign companies are excluded. Following related accounting studies in this area, financial firms are dropped from the sample are the change in non-cash current assets, given by the change in current assets with less the change in cash. CL is the change in current liabilities excluding short term debt and taxes payable, given by the change in current liabilities minus the change in debt included in current liabilities and minus the change in income taxes payable. DEP is depreciation and amortization. The components are further defined as AR the change in 
accounts receivable; INV the change in inventories (DeAngelo L., 1986); OCA the change in other current assets; AP the change in accounts payable; and OCL the change in other current liabilities. As the largeness of all these items vary with the overall size of the firm's balance sheet, we follow the accounting literature and scale each item by average total assets (the average of total assets, Compustat data, at the beginning and end of the fiscal year). Since we are interested in firms' operating performance we focus on profitability before financing costs and taxes. Our assessment of earnings is thus operating income after depreciation (before interest expense, taxes and special items), corresponding to Compustat annual data. We measure all variables at the end of April each year from 2007 to 2011. All firms with available data are included in the sample, regardless of their fiscal year-ends. Accruals comprise the changes in various working capital accounts, so to give some perspective we begin by examining the underlying working capital items in panel A. Current assets is the dominant item, representing 47.1 percent of total assets for the median firm. Accounts receivable and inventory make up the bulk of current assets, with each item accounting for more than 20 percent of total assets for a normal firm. Panel B provides information on the individual accrual items. The largest accrual item is depreciation, but it displays little variability across firms, as manifested by the low standard deviation. The items that contribute most to differentiating accruals across firms are changes in accounts receivable and changes in inventory. The standard deviation of each of these items exceeds 7 percent. Total accruals display large crosssectional variability, with a standard deviation of 10.2 percent. This variability is close in magnitude to the average level of earnings (as a percent of total assets). The implication, then, is that changes in accruals that may not appear unusual can lead to substantial changes in reported earnings.

\section{1. The role of nondiscretionary and discretionary accruals item}

As business conditions such as sales vary across firms, so do working capital requirements and thereby the level of accruals. Controlling for the effects of business conditions may help tease out more clearly the role of managerial discretion in using accruals to manipulate earnings. In this section we implement this idea by decomposing the level of accruals into nondiscretionary and discretionary components. The nondiscretionary component captures the impact of business conditions while the discretionary portion reflects managerial choices. Our strategy parallels other approaches in the accounting literature for distinguishing between non-discretionary and discretionary accruals (Dichow P., 2002).

Few firms have sufficiently long time series to permit reliable estimation of a regression model to extract the discretionary portion of accruals. Instead we rely on a parsimonious model. First we relate the level of each component of working capital for a firm to its current sales .

\section{HYPOTHESIS}

Major hypotheses: there is a significant relationship between stock return and Earnings Quality. Minor hypotheses 1: there is a significant relationship between stock return and level of accruals item. Minor hypotheses 2: there is a significant relationship between stock returns and levels of discretionary and nondiscretionary accruals item.

\section{1. Tests of hypothesis}

To test the hypothesis that sub-components of the accrual accounting must be identified and then the difference between the rate of return is compared between the groups, for this first. 
The five companies, the change in accounts receivable, inventory, other Current assets, accounts payable and other current liabilities in 2007 to 5 categories Sorted and classified by category of first to fifth. The corresponding average return per Calculated and then compared with the average of those years have been. In the main hypothesis we tested of stock return and Earnings Quality separately. We divided the firms into five groups and six year in according to amount of accruals. Then we compared the stock return in the first and fifth portfolios. On the other hand, we measured stock return in firms that had the highest and lowest accruals. We predict that firms with highest accruals have more return that firms with lowest accruals. On the other hand, it seems that these firms have more earning quality. Then we compare the stock return in each group. Table 1 shows the results:

Table 1. stack return on average accrual accounting firms.

\begin{tabular}{|c|c|c|c|c|c|c|c|}
\hline $\begin{array}{c}\text { Stack } \\
\text { return }\end{array}$ & 1 & 2 & 3 & 4 & 5 & T statistics & sig \\
\hline 2007 & 0.0021 & 0.179 & 0.209 & 0.0028 & 0.278 & -1.167 & 0.251 \\
\hline 2008 & 0.602 & 0.901 & 0.268 & 0.329 & 0.420 & 0.856 & 0.398 \\
\hline 2009 & 0.0078 & 0.559 & 0.316 & 0.0037 & 0,225 & -0.454 & 0.653 \\
\hline 2010 & 0.192 & 0.392 & 0.528 & 0.436 & 0.446 & -1.232 & 0.226 \\
\hline 2011 & 0.111 & 0.0069 & 0.534 & 0.404 & 0.691 & -1.264 & 0.220 \\
\hline
\end{tabular}

In the previous section it was shown that the effect of the components of accrual accounting. In this section, the further classified into two categories: voluntary and involuntary commitment figures to test the effect of is presented. items refers to components that are expected to help Management is not involved in the creation or in other words the exchange to occur naturally. To test the main hypotheses are as follows: As shown, there is no significant difference between the stock return. On the other hand, the stock return have been shown, in the fifth quartile the average of stock returned in the year 2007 is 0.446 , two years after that is 0.0049 in the second quartiles we see that these amount are 0.392 and 0.0071 respectively.

We can find out that stock return of high-accrual firms' increase or maintain in the current year and one year ahead. But we see that these amount decrease two years after. We can conclude that the market reacts with a time-lag to accrual quality. Therefore we cannot reject the null hypothesis. We present the results in Table 2. 
Table 2. Comparing of average of stock return in according to accruals.

\begin{tabular}{|c|c|c|c|c|c|c|c|}
\hline $\begin{array}{c}\text { Quartiles of } \\
\text { acruals }\end{array}$ & 1 & 2 & 3 & 4 & 5 & T statistics & sig \\
\hline 2007 & 0.22 & 0.005 & 0.007 & -0.133 & 0.14 & -1.336 & 0.19 \\
\hline 2008 & 0.008 & 0.41 & 0.204 & 0.00014 & 0.004 & 0.182 & 0.85 \\
\hline 2009 & -0.005 & 0.43 & 0.188 & -0.0082 & 0.10 & -0.96 & 0.340 \\
\hline 2010 & 0.25 & 0.0009 & 0.0056 & 0.117 & 0.007 & -2.10 & 0.052 \\
\hline 2011 & -0.24 & -0.26 & 0.0053 & 0.0069 & 0.34 & -1.44 & 0.16 \\
\hline
\end{tabular}

We see that the stock return has not significant differences. Therefore we couldn't reject the second hypothesis. Note that abnormal return in the fifth quartile of base year $(0.0075)$ increase to 0.348 for the next year and then decrease significantly to -0.118 for two years after. We could interpret this as delaying in reaction to accruals reporting. returns of the first quartile were negative except for 2007. This might indicate of under estimation of lower accrual firms. In this study we changed the base year and retest the hypothesis. We showed the results in appendix. The results were similar to Table 2 and 3. For testing the hypothesis about accrual component we divide them in according to 5 categories: changes in accounts receivable, inventory, other current assets accounts payable, other current liabilities. Then we measured and sorted firms in according to these amounts. Then we compare the average return for each quartile in each group. We showed the results in Table 3.

Table 3. Testing the differences between accrual items

\begin{tabular}{|c|c|c|c|c|c|c|c|c|}
\hline $\begin{array}{c}\text { Accrual } \\
\text { components }\end{array}$ & year & 1 & 2 & 3 & 4 & 5 & $\begin{array}{c}\mathrm{T} \\
\text { statistics }\end{array}$ & sig \\
\hline \multirow{3}{*}{$\begin{array}{c}\text { Changes in } \\
\text { accounts } \\
\text { receivable }\end{array}$} & 2010 & 0.866 & 0.313 & 0.297 & 0.297 & 0.430 & 0.941 & 0.353 \\
\cline { 2 - 9 } & 2011 & 0.834 & 0.509 & 0.425 & 0.171 & -0.123 & 2.194 & 0.035 \\
\hline \multirow{3}{*}{$\begin{array}{c}\text { Changes in } \\
\text { inventory }\end{array}$} & 2012 & 0.305 & 0.488 & 0.0074 & 0.296 & - & 1.561 & 0.127 \\
\cline { 2 - 9 } & 2011 & 0.734 & 0.0037 & 0.826 & 0.132 & 0.0065 & 1.393 & 0.172 \\
\hline \multirow{2}{*}{$\begin{array}{c}\text { Changes in } \\
\text { other } \\
\text { current } \\
\text { assets }\end{array}$} & 2010 & 0.0019 & 0.539 & 0.599 & 0.604 & 0.229 & -1.046 & 0.302 \\
\cline { 2 - 9 } & 2011 & 0.405 & 0.176 & 0.0061 & 0.354 & 0.838 & -0.744 & 0.461 \\
\hline \multirow{2}{*}{$\begin{array}{c}\text { Changes in } \\
\text { account } \\
\text { payable }\end{array}$} & 2010 & 0.576 & 0.0074 & 0.200 & 0.100 & 0.511 & -1 & 0.324 \\
\cline { 2 - 9 } & 2011 & 0.424 & 0.726 & 0.386 & 0.435 & -0.153 & 1.671 & 0.103 \\
\hline $\begin{array}{c}\text { Changes in } \\
\text { other }\end{array}$ & 2012 & 0.465 & 0.327 & 0.386 & 0.0078 & 0.0020 & 2.050 & 0.048 \\
\cline { 2 - 9 } $\begin{array}{c}\text { current } \\
\text { liabilities }\end{array}$ & 2011 & 0.0082 & 0.949 & 0.0036 & 0.0050 & 0.718 & -1.760 & 0.087 \\
\cline { 2 - 9 } & 2012 & 0.259 & 0.304 & 0.0015 & 0.324 & 0.215 & 0.053 & 0.958 \\
\hline
\end{tabular}


We couldn't reject the null hypothesis about items of accruals. The return average of fifth quartiles of changes in receivable accounts and inventory had decreased in the years after portfolio formation. This indicated that investors had more sensitive actions in the following years. Also, changes in stock return related to accounts payable and other current liabilities had decreased, but two years after we see that these amounts have decreased. This is indication of under-reaction of decision makers and investors to changes in these components.in table 4 descriptive statistics of accrual accounting and its related components Have been reported:

Table 4. Descriptive statistics, elements of accrual accounting.

\begin{tabular}{|c|c|c|c|c|}
\hline Statistics & $\begin{array}{c}\text { Change in non } \\
\text { cash } \\
\text { current assets }\end{array}$ & $\begin{array}{c}\text { Change in current } \\
\text { liabilities }\end{array}$ & $\begin{array}{c}\text { Changein account } \\
\text { receivable }\end{array}$ & $\begin{array}{c}\text { Change in } \\
\text { inventory }\end{array}$ \\
\hline Average & 0.122 & 0.113 & 0.016 & 0.032 \\
\hline Median & 0.103 & 0.111 & 0.018 & 0.030 \\
\hline S.D & 0.484 & 0.264 & 0.126 & 0.127 \\
\hline First Quartiles & 0.020 & 0.005 & 0.126 & -0.012 \\
\hline Third quartile & 0.210 & 0.219 & 0.079 & 0.091 \\
\hline
\end{tabular}

We present descriptive statistics of variables in Table 5 Non-cash current assets are 69 percent of average of total assets. Current liabilities are 67 percent of average of total assets. The average of earnings is greater than cash flows. Standard deviation of accruals is 0.241 that are greater than standard deviation of earnings and cash flows the variation of accruals indicate that there is possible to manipulate or smooth earning. Standard deviation of changes in non cash current assets is greater than standard deviation of change in current liabilities $(0.484$ versus 0.264). It maybe because accruals are more affected by changes in current assets. Standard deviation of changes in accounts receivable and changes in inventory have not significant difference ( 0.126 and 10.127 respectively). But average of changes in inventory (0.032) is greater than the average of changes in accounts receivable $(0.016)$. The average of changes in accounts payable is -0.022 it means that firms have intended to decrease accounts payable in these periods. Also standard deviation of accounts payable is more than standard deviation of components of current assets $(0.139)$. Therefore variations of changes in accounts payable are more than the others.

\section{CONCLUSION}

This paper describes the role of accrual accounting and earnings quality analysis was investigated. Accrual accounting the ability to work may affect the quality of earnings. It is expected Been increasing interest accrual accounting reduces quality, and the market reaction following Have. The main assumptions and results of the total accrual accounting Is that we can not accept returns of firms with high and low level of accrual accounting Is affected the aim of this study was to investigate the Relationship between Earnings Quality 
and Stock Returns in Tehran Stock Exchange. As one may know accrual can be manipulated and thus accruals affect EQ. as one might expect that increasing in accruals leads to decreasing EQ and market participants react them, but the result shoed that there is no significant difference between firms with highest and lowest accruals. On the other hand, average return is equal in these groups. The findings also showed that components of accruals including changes in accounts receivable, inventory, other current assets, current liabilities and other current liabilities have not significant effect on stock return. As a whole this study demonstrated that for discretionary accruals, decreasing of stock return is greater than the decreasing of stock return for non-discretionary accruals.

\section{References}

[1] Brown L., Sivakumar K., Comparing the quality of three earnings. Working Paper, Georgia State University, 2001.

[2] Collins D., Kothari S. P., Journal of accounting and economics 11 (1989) 143-181.

[3] Cornell B., Landsman R., Financial analysts journal 59 (2003) 20-29.

[4] DeAngelo L., The accounting review 61 (1986) 400-420.

[5] Dichow P., Dichev I., The accounting review 77 (2002) 35-59.

[6] Financial Accounting Standards Board, Statement of financial accounting concept 1, Stamford, CT., 1983.

[7] Hand J., The accounting review 64 (1989) 587-623.

[8] Khajavi P., Nazemi A., Accounting and Auditing 40 (2005) 37-60.

[9] Lougee B., C. Marquardt C., Account. Rev. 79(3) (2004) 769-795

[10] Mohammad Hadi Zohdi, Hashem Valipour, Mohadese Hasani, Mohammad Reza Dalvand, Maryam Zohdi, Research Journal of Applied Sciences, Engineering and Technology 4(16) (2012) 2632-2638

[11] Warfield T. Wild J., Accounting Review 67 (1992) 821-842. 